Jurnal Indonesia Sosial Teknologi: p-ISSN: 2723 - 6609

e-ISSN : 2745-5254

Vol. 2, No. 11 November 2021

\title{
ANALISIS PENENTUAN PEMBANGUNAN DERMAGA BERDASARKAN ANALISIS CITRA SENTINEL 2A DI PERAIRAN DELTA WULAN KOTA PESISIR DEMAK
}

\section{Tedi Prayoga ${ }^{1}$ Lita Sari Barus ${ }^{2}$}

Program Studi Kajian Pengembangan Perkotaan, Sekolah Kajian Stratejik dan Global, Universitas Indonesia ${ }^{1,2}$

Email: tediprayogaui@gmail.com ${ }^{1}$

\begin{abstract}
Abstrak
Delta Wulan merupakan daerah strategis di wilayah pesisir utara Pulau Jawa yang banyak dimanfaatkan untuk aktivitas manusia seperti pertambakan, pemukiman penduduk, tanaman mangrove, dan jalur transportasi kapal nelayan. Hal tersebut berdampak pada besarnya kandungan material padatan tersuspensi yang terdapat pada sungai. Pengamatan sebaran material padatan tersuspensi dibutuhkan untuk mengetahui pola sedimentasi untuk mencegah pendangkalan dan banjir. Tujuan dari penelitian ini adalah untuk mengetahui sebaran material padatan tersuspensi di Delta Wulan menggunakan metode pengindraan jauh. Data yang digunakan dalam penelitian ini adalah citra satelit Sentinel-2A, konsentrasi material padatan tersuspensi hasil uji gravimetri, pasang surut dihitung dengan menggunakan metode Admiralty dan arus pemodelan numerik menggunakan Mike 21 Flow Model FM. Pengolahan data menggunakan Metode Regresi (Linear, Eksponensial dan Logaritmik). Hasil analisis data menunjukkan bahwa konsentrasi material padatan tersuspensi di sekitar Delta Wulan relatif tinggi, konsentrasi tertinggi terdapat di arah barat muara sungai atau di daerah yang berupa delta. Model regresi terbaik, yaitu model regresi exponential antara nilai band merah dengan nilai konsentrasi data lapangan dengan nilai uji akurasi nilai RMSE sebesar 3,8895. Berdasarkan hasil yang didapat, dapat disimpulkan jika penggunaan citra satelit dapat digunakan untuk penentuan pembangunan dermaga di Delta Wulan, Kota Demak.
\end{abstract}

Kata kunci: material padatan tersuspensi; pengindraan jauh; sentinel-2A, mike 21, kota pesisir demak

\footnotetext{
Abstract

Delta Wulan is a strategic area in the northern coastal region of Java Island which is widely used for human activities such as aquaculture, residential areas, mangrove plants, and fishing boat transportation routes. This has an impact on the amount of total suspended solid material contained in the river. Observation of the distribution of suspended solids is needed to determine the sedimentation pattern to prevent silting and flooding. The purpose of this study was to determine the distribution of total suspended solids in Delta Wulan using remote sensing methods. The data used in this research are Sentinel-2A satellite imagery, the concentration of total suspended solids from the gravimetric test results, the tides are calculated using the Admiralty method and the flow of numerical modeling using the Mike 21 Flow Model
} 
FM. Data processing using the Regression Method (Linear, Exponential and Logarithmic). The results of data analysis show that the concentration of total suspended solids around the Wulan Delta is relatively high, with the highest concentration in the west of the river estuary or in areas in the form of deltas. The best regression model is the exponential regression model between the red band value and the field data concentration value with the RMSE accuracy test value of 3.8895. Based on the results obtained, it can be concluded that the use of satellite imagery for the analysis of determining the construction of a pier in the Wulan Delta, Demak City.

Keywords: Total Suspended Solid, Remote Sensing, Sentinel-2A, Mike 21, Demak Waterfront City.

\section{Pendahuluan}

Kota Pesisir (Waterfront City) adalah kawasan perkotaan yang berada di tepi air (laut, danau, atau sungai), yang memiliki karakteristik open access dan juga multi fungsi, namun sangat rentan terhadap kerusakan serta perusakan. Muara Sungai Wulan yang ada di Kota Pesisir Demak merupakan daerah strategis di wilayah pesisir utara Pulau Jawa yang banyak dimanfaatkan untuk aktivitas manusia seperti pertambakan, pemukiman penduduk, tanaman mangrove, dan jalur transportasi kapal nelayan. Sungai Wulan memiliki tingkat sedimentasi yang tinggi dan mampu membentuk delta dimuara sungai, delta sungai wulan telah mengalami sedimentasi dan abrasi yang signifikan dalam perkembanganya dari tahun 1994 sampai dengan tahun 2015 (Putri, Muskananfola, \& Hendrarto, 2017). Kondisi sedimentasi di suatu wilayah perairan dapat diketahui melalui seberapa besar kisaran material padatan tersuspensi di wilayah tersebut (Jiyah,

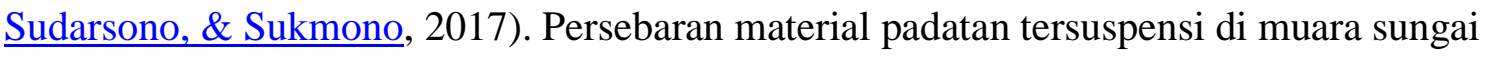
dipengaruhi oleh faktor -faktor oseanografi, pasang surut dapat membangkitkan arus pasang surut yang dapat membawa material padatan tersuspensi yang akan mengendap di suatu perairan (Qhomariyah, 2015).

Penelitian terdahulu yang pernah dilakukan di Delta Sungai Wulan menyebutkan bahwa nilai konsentrasi material padatan tersuspensi tertinggi terdapat pada sekitar muara sungai dan semakin berkurang kearah laut lepas dengan nilai konsentrasi berkisar antara $55 \mathrm{mg} / \mathrm{l}$ - $129 \mathrm{mg} / \mathrm{l}$ (Manurung, Suryoputro, \& Hariadi, 2017). Sedimentasi yang tinggi di wilayah muara akan berakibat pendangkalan, sehingga hal tersebut akan mengganggu aktivitas nelayan dan konsentrasi material padatan tersuspensi yang tinggi dapat mereduksi penetrasi cahaya terhadap air sehingga berdampak pada berkurangnya produksi utama dari fitoplankton yang dapat menggangu aktivitas tambak budidaya (Qanita \& Subiyanto, 2019). Penelitian mengenai “Analisis Material Padatan Tersuspensi Berdasarkan Analisis Citra Satelit Sentinel 2A di Perairan Delta Wulan Kota Demak Provinsi Jawa Tengah" belum dilakukan didaerah tersebut dengan menggunakan citra satelit sentinel 2A dan arus pasang surut. Metode pengindraan jauh dengan citra satelit Sentinel 2A memiliki kemampuan menembus kolom air dengan resolusi spasial $10 \mathrm{~m}$ dan resolusi temporal 5 hari serta memiliki area sapuan sebesar $290 \mathrm{~km}^{2}$ telah dikembangkan untuk mengetahui nilai sebaran material padatan tersuspensi (Gatti \& Bertolini, 2015). 
Pemetaan dan estimasi nilai material padatan tersuspensi menggunakan pengindraan jauh memiliki keunggulan dalam hal penghematan biaya dan waktu serta data yang mudah didapatkan telah dikembangkan menggunakan berbagai pendekatan algoritma dan transformasi spektral, pemetaan dan estimasi dikategorikan kedalam empat kelompok pendekatan antara lain regresi sederhana (korelasi antara band tunggal dengan data insitu), teknik spectral mixing, teknik rasio band menggunakan dua atau lebih band, dan regresi berganda menggunakan berbagai band dan pengukuran insitu (Hossain, Jia, \& Chao, 2010). Penelitian ini bertujuan untuk memodelkan sebaran material padatan tersuspensi di Perairan Delta Wulan, diharapkan bisa menjadi acuan bagi pemerintah dan pelaku kegiatan terkait sebagai langkah awal pencegahan pendangkalan dan banjir di Kota Pesisir Demak.

\section{Metode Penelitian}

Materi yang digunakan dalam penelitian ini meliputi data utama dan data pendukung. Data utama yaitu citra Satelit Sentinel-2A (Perekaman 15 November 2019), Data arus dan data konsentrasi material padatan tersuspensi yang didapatkan dari hasil survei lapangan di Perairan Delta Wulan Demak. Data pendukung meliputi data peta batimetri nasional dan data pasang surut perairan Delta Wulan Demak hasil pengukuran BIG November 2019), dan Peta Rupabumi Indonesia Kota Demak skala 1:25000.

Wilayah kajian penelitian berada di Perairan Delta Wulan, Kota Demak. Wilayah penelitian batasan kajian berkoordinat $110^{\circ} 29^{\prime} 32^{\prime \prime}$ Bujur Timur sampai $110^{\circ} 34^{\prime} 58^{\prime \prime}$ Bujur Timur dan 642'4”' Lintang Selatan sampai 646’12” Lintang Selatan.

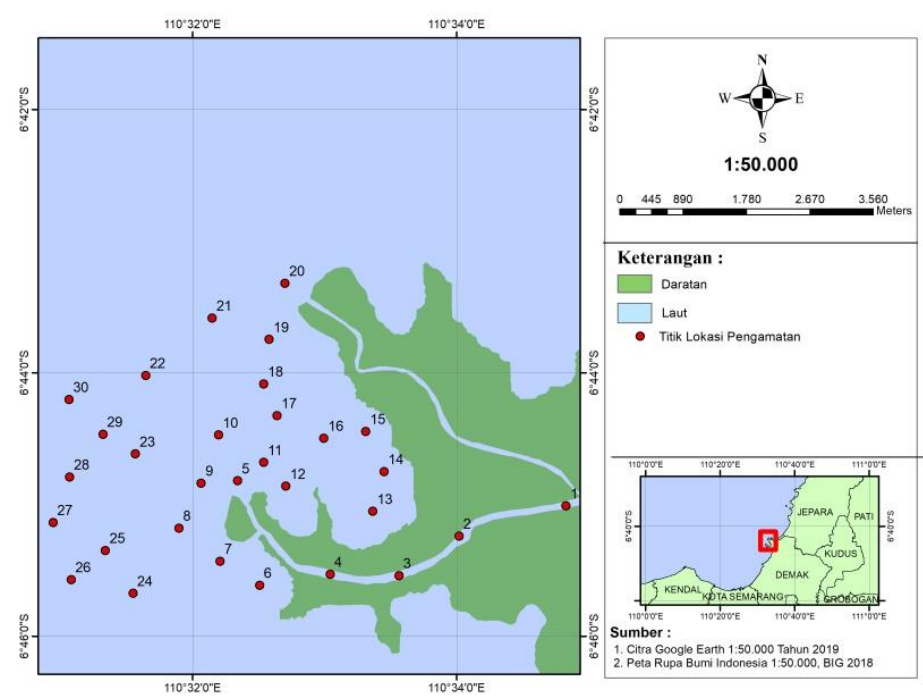

Gambar 1. Lokasi Penelitian

Metode yang digunakan dalam penelitian ini adalah metode kuantitatif karena telah memenuhi kaidah- kaidah ilmiah yaitu konkret, obyektif, rasional, sistematis. Metode kuantitatif memiliki karakteristik sistematis, terencana dan terstruktur dari awal hingga akhir penelitian (Suryono \& Rochaddi, 2017). Metode pengambilan sampel dalam penelitian ini menggunakan stratified random sampling. Penentuan titik lokasi 
pengambilan sampel dilakukan dengan cara membagi area sampling menjadi 3 kelas berdasarkan pengolahan konsentrasi MPT citra Sentinel-2 perekaman 5 November 2019. Jumlah sampel yang diambil yakni sebanyak 30 sampel. Sampel sedimen yang tersuspensi diambil menggunakan botol nansen atau water sampler (Atmodjo, 2011). Pengukuran arus laut dengan metode Eulerian pada satu titik secara insitu pada 0d. Pengukuran arus terdiri 2 tahap. Dalam penentuan arah arus, drifter dilepas ke perairan selama 1 menit. Arah drifter diukur dengan kompas tembak. Untuk mengukur kecepatan arus, currentmeter dimasukkan ke dalam permukaan air ke arah arus lalu diukur dengan perputaran rotor. Semua data dicatat dalam tabel pengamatan.

Konsentrasi MPT yang terkandung dalam sampel dapat diketahui dengan menggunakan metode gravimetri. Massa sedimen tersuspensi pada sampel air laut dapat diketahui dengan menimbang selisih berat kering kertas saring setelah dan sebelum dilakukan filtrasi (Poerbandono \& Djunarsjah, 2005). Data pengindraan jauh yang direkam umumnya merupakan data mentah (raw data), sehingga perlu dilakukan pengolahan secara digital. Penajaman citra dilakukan dengan mentransformasikan nilai spektral menjadi konsentrasi MPT menggunakan formula yang diturunkan dari algoritma terbaik. Algoritma yang digunakan menggunakan persamaan yang diperoleh melalui analisis regresi antara nilai piksel pada kanal yang diuji dengan data MPT lapangan hasil uji laboratorium. Kanal yang digunakan yaitu kanal biru, hijau, merah dan NIR yang terdiri atas kanal tunggal dan kombinasi masing-masing kanal dengan operasi matematika sederhana (penjumlahan, pengurangan, perkalian dan pembagian). Persamaan algoritma Metode Regresi diperoleh melalui pendekatan secara linear dan eksponensial.

Pengolahan data arus dilakukan dengan menggunakan software MIKE 21 dan ArcGis 10.3. Penggunaan software ini bertujuan untuk memodelkan pola pergerakan arus berupa kecepatan dan arah arus dalam penelitian. Data Pasang surut dianalisis dengan metode admiralty untuk mendapatkan konstanta harmonik pasang surut. Konstanta yang dihasilkan dapat digunakan untuk mengetahui tipe pasang surut dengan menggunakan formula Formzahl. Penentuan tipe pasang surut dilakukan dengan melihat nilai Formzahl.

\section{Uji Validasi Pemodelan Sebaran Material Padatan Tersuspensi dan Arus}

Uji Validasi Hasil Pendugaan algoritma dan pemodelan arus dengan Sampel Lapangan Validasi data citra merupakan proses statistik yang berguna untuk mengetahui perbandingan antara data model dengan data lapangan. Perbandingan ini bertujuan untuk mengetahui seberapa besar kemiripan antara data model dengan data yang diperoleh di lapangan (Huang, Pan, Kuang, Zeng, \& Chen, 2013). Nilai kebenaran data dapat diketahui dengan menghitung seberapa besar error (kesalahan) pada data yang didapat. Nilai kesalahan dapat dihitung dengan rumus Root Mean Square Error (RMSE).

\begin{tabular}{cccc}
\hline Uji Validasi & \multicolumn{3}{c}{ Persamaan } \\
\hline $\begin{array}{l}\text { Root Mean } \\
\text { (RMSE) }\end{array}$ & Square & Error & $\begin{array}{l}\text { Root Mean Square Error } \\
\text { (RMSE) }\end{array}$ \\
& RMSE $=\sqrt{\frac{\sum_{i=1}^{n}\left(x_{m}-x_{e}\right)^{2}}{n}}$ \\
\hline
\end{tabular}


Analisis Penentuan Pembangunan Dermaga Berdasarkan Analisis Citra Sentinel 2a di Perairan Delta Wulan Kota Pesisir Demak

Keterangan: $x_{m}=$ Nilai hasil pengukuran lapangan yang dianggap benar; $x_{e}=$ Nilai hasil pengolahan

$$
n \quad=\text { Jumlah data }
$$

\section{Hasil dan Pembahasan}

Hasil analisis gravimetri menunjukkan bahwa nilai tertinggi terdapat pada stasiun 16 dengan konsentrasi MPT sebesar 99,2 mg/l. Nilai terendah terdapat pada stasiun 30 dengan konsentrasi MPT sebesar 44,8 mg/l

(Tabel 2).

\begin{tabular}{|c|c|c|c|c|c|c|}
\hline \multirow[t]{2}{*}{ Stasiun } & \multirow[t]{2}{*}{ Lintang } & \multirow[t]{2}{*}{ Bujur } & \multirow[t]{2}{*}{ Kedalaman (m) } & \multicolumn{3}{|c|}{ Konsentrasi $(\mathrm{mg} / \mathrm{l})$} \\
\hline & & & & $0,2 \mathrm{D}$ & $0,6 \mathrm{D}$ & $0,8 \mathrm{D}$ \\
\hline 1 & $6^{\circ} 45^{\prime} 0.60^{\prime \prime S}$ & $110^{\circ} 34^{\prime} 49.68^{\prime \prime E}$ & -1.72 & 49,6 & 50,6 & 52,8 \\
\hline 2 & $6^{\circ} 45^{\prime} 17.10^{\prime \prime S}$ & $110^{\circ} 34^{\prime} 2.88^{\prime \prime} \mathrm{E}$ & -1.60 & 50,6 & 52,2 & 54,4 \\
\hline 3 & $6^{\circ} 45^{\prime} 32.41^{\prime \prime S}$ & $110^{\circ} 33^{\prime} 33.79^{\prime \prime E}$ & $-1,55$ & 53,4 & 54,6 & 55,2 \\
\hline 4 & $6^{\circ} 45^{\prime} 31.77^{\prime \prime S}$ & $110^{\circ} 33^{\prime} 2.66^{\prime \prime E}$ & -1.58 & 55,8 & 56,00 & 56,2 \\
\hline 5 & $6^{\circ} 44^{\prime} 58.27 " \mathrm{~S}$ & $110^{\circ} 32^{\prime} 23.53 " \mathrm{E}$ & -1.40 & 67,2 & 68,4 & 70,6 \\
\hline 6 & $6^{\circ} 45^{\prime} 36.78^{\prime \prime S}$ & $110^{\circ} 32^{\prime} 30.40^{\prime \prime} \mathrm{E}$ & $-1,76$ & 87,2 & 87,4 & 88,6 \\
\hline 7 & $6^{\circ} 45^{\prime} 25.85^{\prime \prime S}$ & $110^{\circ} 32^{\prime} 12.42^{\prime \prime} \mathrm{E}$ & $-1,83$ & 75,0 & 76,2 & 77,0 \\
\hline 8 & $6^{\circ} 45^{\prime} 12.72^{\prime \prime S}$ & $110^{\circ} 31 ' 53.91 " \mathrm{E}$ & $-2,43$ & 60,4 & 60,8 & 61,2 \\
\hline 9 & $6^{\circ} 44 ' 50.31 " \mathrm{~S}$ & $110^{\circ} 32^{\prime} 4.01^{\prime \prime E}$ & $-2,21$ & 74,6 & 74,8 & 75,2 \\
\hline 10 & $6^{\circ} 44 ' 28.31 " \mathrm{~S}$ & $110^{\circ} 32^{\prime} 11.81^{\prime \prime E}$ & $-2,12$ & 75,6 & 76.2 & 78,4 \\
\hline 11 & $6^{\circ} 44^{\prime} 40.79^{\prime \prime S}$ & $110^{\circ} 32^{\prime} 32.17^{\prime \prime E}$ & $-2,34$ & 91,2 & 92,8 & 93,6 \\
\hline 12 & $6^{\circ} 44 ' 51.65^{\prime S} \mathrm{~S}$ & $110^{\circ} 32^{\prime} 42.47 " \mathrm{E}$ & $-2,53$ & 93,6 & 94,4 & 95,2 \\
\hline 13 & $6^{\circ} 45^{\prime} 3.13^{\prime \prime S}$ & $110^{\circ} 33^{\prime} 21.81^{\prime \prime E}$ & $-2,20$ & 89,4 & 90,2 & 91,4 \\
\hline 14 & $6^{\circ} 44 ' 45.03 " \mathrm{~S}$ & $110^{\circ} 33^{\prime} 26.92^{\prime \prime E}$ & $-2,76$ & 94,2 & 95,2 & 96,2 \\
\hline 15 & $6^{\circ} 44^{\prime} 26.73^{\prime \prime S}$ & $110^{\circ} 33^{\prime} 18.59^{\prime \prime} \mathrm{E}$ & $-2,68$ & 97,2 & 97,4 & 98,2 \\
\hline 16 & $6^{\circ} 44^{\prime} 29.77 " \mathrm{~S}$ & $110^{\circ} 32^{\prime} 59.72 " \mathrm{E}$ & $-2,78$ & 98,2 & 98,6 & 99,2 \\
\hline 17 & $6^{\circ} 44^{\prime} 19.49 " \mathrm{~S}$ & $110^{\circ} 32^{\prime} 38.34^{\prime \prime E}$ & $-2,80$ & 90,2 & 90,4 & 92,8 \\
\hline 18 & $6^{\circ} 44^{\prime} 5.05^{\prime \prime S}$ & $110^{\circ} 32^{\prime} 32.14^{\prime \prime E}$ & $-2,87$ & 61,4 & 62,2 & 63,6 \\
\hline 19 & $6^{\circ} 43^{\prime} 40.48^{\prime \prime S}$ & $110^{\circ} 33^{\prime} 6.79^{\prime \prime} \mathrm{E}$ & $-2,34$ & 75,8 & 76,2 & 77,2 \\
\hline 20 & $6^{\circ} 43 ' 36.74 " \mathrm{~S}$ & $110^{\circ} 32^{\prime} 41.12^{\prime \prime E}$ & $-3,21$ & 57,6 & 58,4 & 59,2 \\
\hline 21 & $6^{\circ} 43 ' 35.04 " \mathrm{~S}$ & $110^{\circ} 32^{\prime} 8.93 " \mathrm{E}$ & $-3,65$ & 58,8 & 59,2 & 60,4 \\
\hline 22 & $6^{\circ} 44^{\prime} 1.19^{\prime \prime S}$ & $110^{\circ} 31^{\prime} 38.75^{\prime \prime E}$ & $-3,86$ & 56,6 & 57,6 & 58,4 \\
\hline 23 & $6^{\circ} 44^{\prime} 36.97 " \mathrm{~S}$ & $110^{\circ} 31^{\prime} 34.03 " \mathrm{E}$ & $-3,75$ & 59,6 & 60,8 & 61,2 \\
\hline 24 & $6^{\circ} 45^{\prime} 40.47 " \mathrm{~S}$ & $110^{\circ} 31^{\prime} 32.71 " \mathrm{E}$ & $-4,15$ & 57,6 & 58,4 & 59,6 \\
\hline 25 & $6^{\circ} 45^{\prime} 20.96 " \mathrm{~S}$ & $110^{\circ} 31 ' 20.22 " \mathrm{E}$ & $-4,65$ & 55,2 & 56,6 & 57,2 \\
\hline 26 & $6^{\circ} 45^{\prime} 34.21 " \mathrm{~S}$ & $110^{\circ} 31^{\prime} 4.73 " \mathrm{E}$ & $-4,87$ & 51,8 & 52,2 & 53,6 \\
\hline 27 & $6^{\circ} 45^{\prime} 8.18^{\prime \prime S}$ & $110^{\circ} 30^{\prime} 56.48^{\prime \prime} \mathrm{E}$ & $-5,62$ & 46,4 & 47,6 & 48,2 \\
\hline 28 & $6^{\circ} 44^{\prime} 47.47 " \mathrm{~S}$ & $110^{\circ} 31^{\prime} 4.10^{\prime \prime E}$ & $-5,68$ & 47,6 & 48,6 & 50,4 \\
\hline 29 & $6^{\circ} 4428.00^{\prime \prime S}$ & $110^{\circ} 31^{\prime} 19.33 " \mathrm{E}$ & $-5,84$ & 46,2 & 47,2 & 48,4 \\
\hline 30 & $6^{\circ} 44^{\prime} 12.15^{\prime \prime S}$ & $110^{\circ} 31 ' 3.64 " \mathrm{E}$ & $-6,52$ & 44,8 & 45,6 & 46,2 \\
\hline
\end{tabular}


Tedi Prayoga, Lita Sari Barus

Berikut hasil pengolahan data pengukuran pasang surut bulan Februari 2020 Kota Demak.

Tabel 5. Tabel Komponen Harmonik Pasut

\begin{tabular}{ccc}
\hline Koefisien & $\mathrm{A}(\mathrm{cm})$ & $\mathrm{g}^{\mathrm{o}}$ \\
\hline S0 & 88,02 & 180 \\
\hline M2 & 13,44 & 39,69 \\
\hline S2 & 9,36 & 299,63 \\
\hline N2 & 7,66 & 1,66 \\
\hline K1 & 21,05 & 250,72 \\
\hline O1 & 5,57 & 95,01 \\
\hline M4 & 1,14 & 261,90 \\
\hline MS4 & 0,44 & 237,53 \\
\hline K2 & 2,53 & 299,63 \\
\hline P1 & 6,94 & 250,72
\end{tabular}

Tipe pasang surut berdasarkan nilai $\mathrm{F}$ (Formzahl) adalah 0,77 sehingga termasuk pasang campuran condong ke harian ganda. Hasil penelitian ini sama dengan penelitian sebelumnya yang dilakukan oleh (Shabari et al. 2019) yang juga memperoleh tipe pasang surut campuran condong ke harian ganda. Tipe pasang surut ini berarti bahwa satu hari terjadi dua kali air pasang dan dua kali air surut, tetapi terkadang terjadi satu kali pasang dan satu kali surut dengan memiliki tinggi dan waktu yang berbeda. Selain itu, didapat nilai elevasi muka air laut berupa HHWL dan MSL secara berurutan adalah 186,41 cm dan 140,42 cm. Grafik pasang surut perairan Kota Demak ditunjukkan dalam Gambar 2.

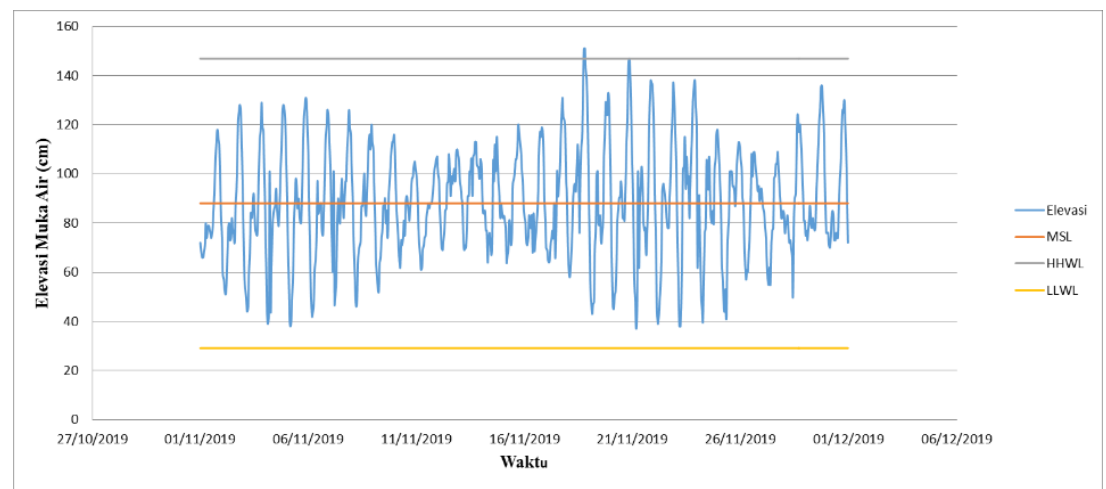

Gambar 2. Grafik Pasang Surut stasiun BIG bulan November 2020

Data batimetri diperoleh dari situs BATNAS (Batimetri Nasional) Badan Informasi Geografi (BIG) dengan datum MSL (Mean Sea Level). Data batimetri ini 
merupakan data digital yang menggambarkan elevasi berupa geometri dan bentuk muka bumi. Susunan data digital terdiri atas nilai koordinat $\mathrm{x}$ dan y yang mewakili distribusi spasial dan sistem koordinat z yang mewakili kedalaman dengan resolusi spasial 6arcsecond. Data BATNAS yang diperoleh dalam format data tif. Untuk mendapatkan nilai kontur kedalaman, diolah dengan software ArcGIS 10.4. Hasil pengolahan batimetri Muara Sungai Wulan menampilkan kontur kedalaman perairan yang dapat dilihat pada Gambar 3.

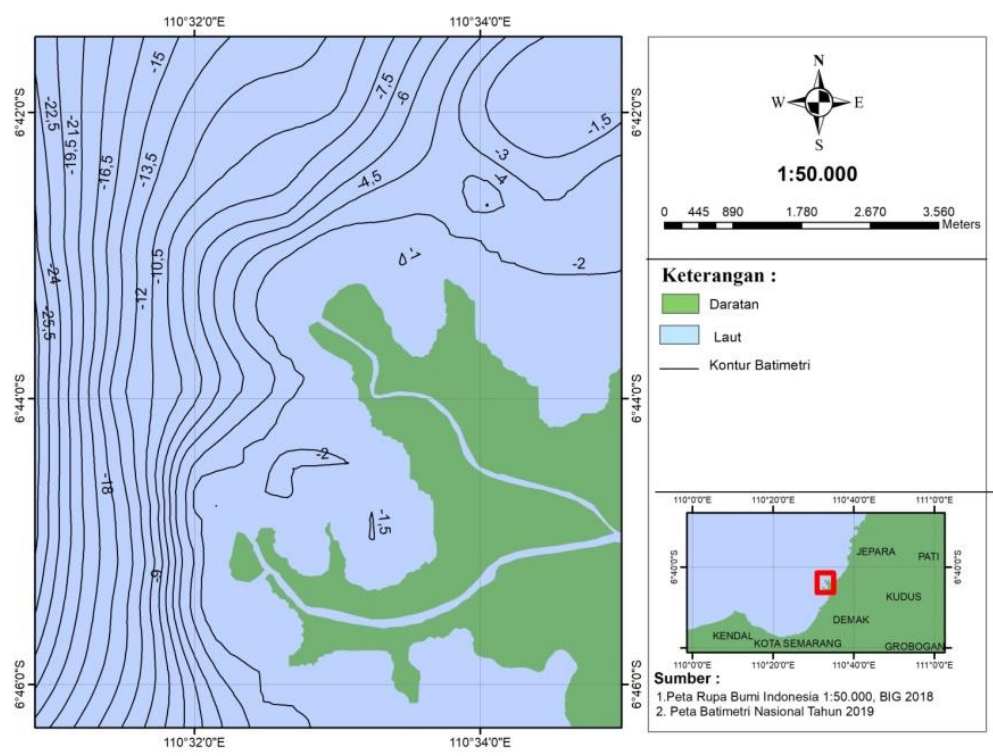

Gambar 3. Kontur Batimetri Delta Wulan

Pengolahan data arus dilakukan dengan metode pemodelan matematik dengan software MIKE 21 Flow Model FM, Hydrodinamic Module. Input data yang digunakan menggunakan data digitasi garis pantai dan data batimetri. Data garis pantai didapatkan dari peta Rupa Bumi Indonesia dan data batimetri dari hasil pengolahan data BATNAS. Hasil yang diperoleh berupa vector plot arus di dalam peta. Vector plot menunjukkan kecepatan dan arah arus, Vector plot menunjukkan kecepatan dan arah arus. Time interval simulasi model dan running model yang diolah pada saat pasang harian, yaitu pada 15 November 2019 pukul 09.30 WIB. Kisaran vector arus model adalah 0,009-0,122 m/s dengan arah arus dominan mengarah ke barat daya dan selatan. Uji akurasi berdasarkan metode RMS ini didapatkan nilai verfikasi kecepatan arus sebesar 0.1180 . Hasil verfikasi ditampilkan kedalam bentuk garfik perbandingan antara data arus pemodelan dengan data arus lapangan. Menurut (Minarrohman, 2017), jika hasil verifikasi arus menunjukan RMS $<1$ dan mendekati 0 maka hasil pemodelan arus yang dijalankan adalah baik dan valid. Sehingga data hasil pemodelan dapat dianalisa lebih lanjut. Peta sebaran pola arus permukaan dapat dilihat pada Gambar 4. 


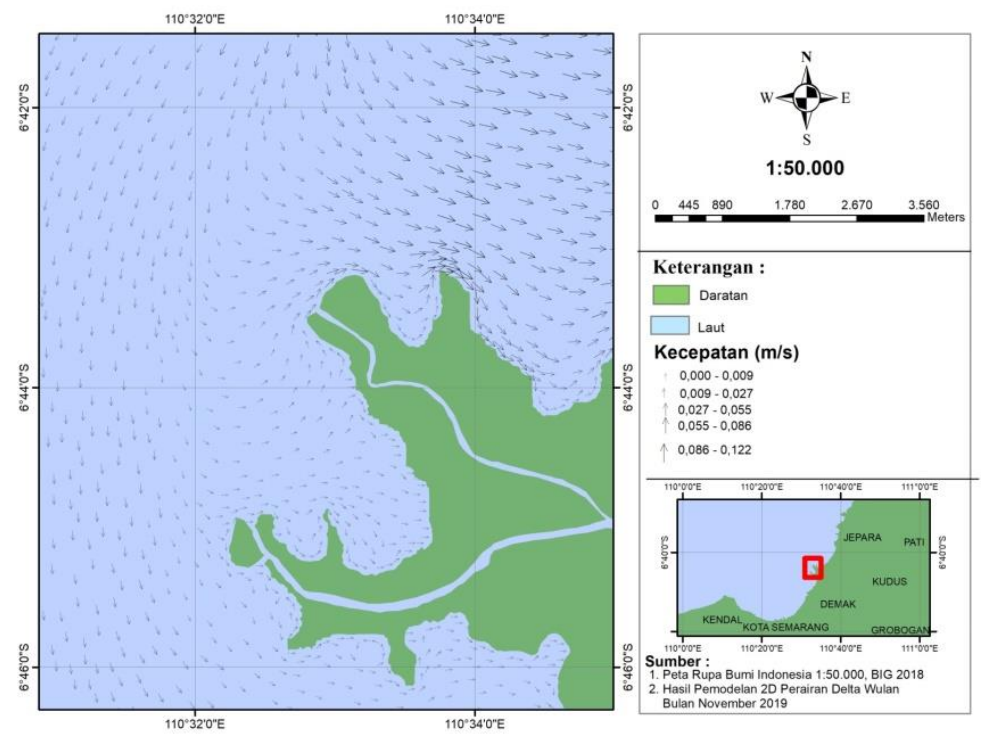

Gambar 4. Pola Arus Perairan Delta Wulan Bulan November 2019

Transformasi spektral yang digunakan adalah transformasi ektrasi data MPT yang didapatkan dari pengolahan data citra Sentinel 2A. Transformasi spektral dipilih berdasarkan kesamaan karakteristik perairan dengan asumsi sedimentasi yang tinggi. Transformasi spektral yang digunakan untukmengekstraksi data MPT dari citra Sentinel 2A ini memanfaatkan band multispectral atau band tampak dan inframerah dekat. Hal itu karena band tampak dan infra merah dekat merupakan band yang peka terhadap kekeruhan air akibat adamya sedimen terlarut yang ada dalam perairan. Berdasarkan pengolahan data hasil algoritma MPT yang didapatkan dari persamaan (linier, eksponensial dan logaritmik) dari nilai Digital Number dengan data konsentrasi material padatan tersuspensi yang didapatkan di lapangan. Pada penelitian pemodelan algoritma dilakukan dengan metode Single band yaitu dengan membandingkan nilai lapangan dengan nilai dari satu band dan metode band rationing atau pembagian yang dilakukan antara dua band. Algoritma yang digunakan yaitu algoritma dengan nilai R2 yang tertinggi.

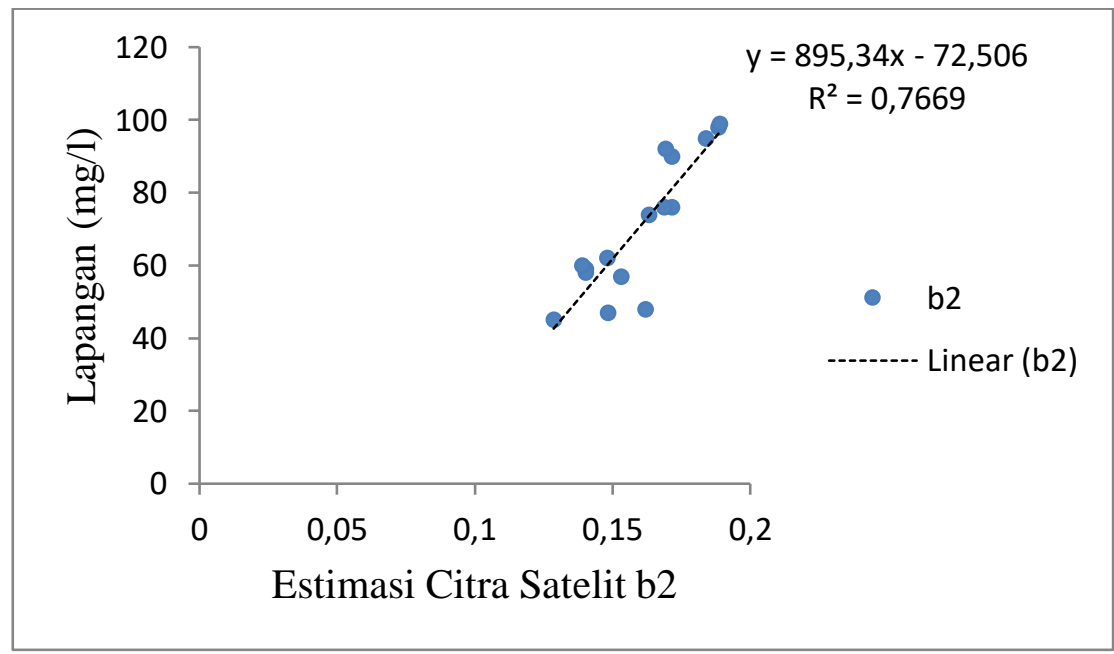


Gambar 5. Grafik Regresi Band 2 dengan konsentrasi MPT lapangan.

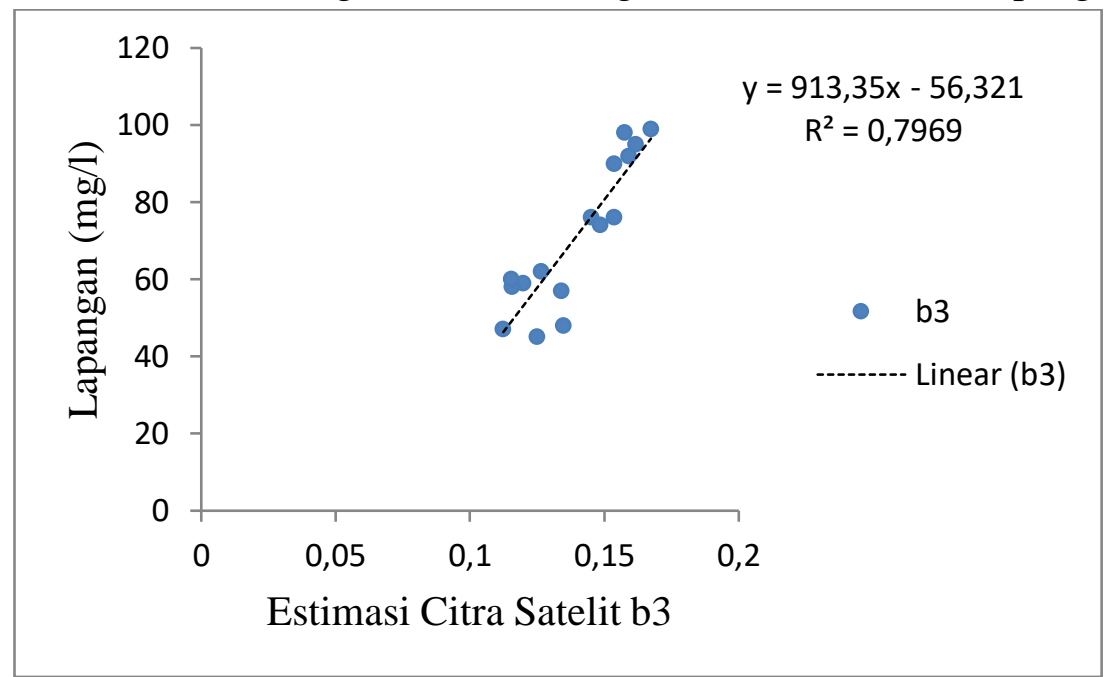

Gambar 6. Grafik Regresi Band 3 dengan konsentrasi MPT lapangan.

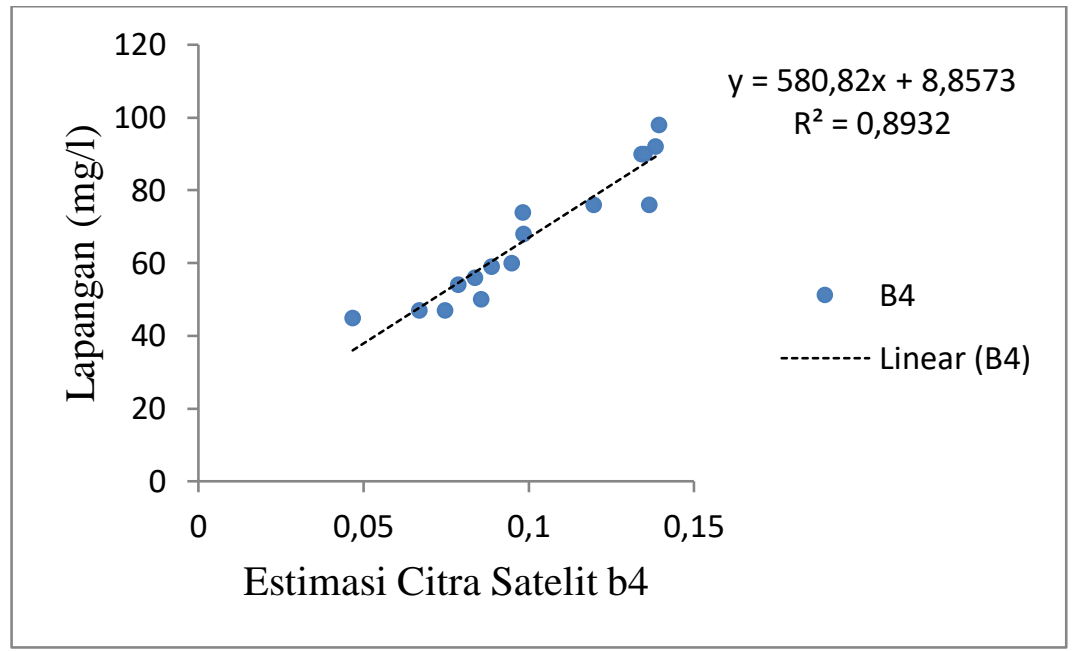

Gambar 7. Grafik Regresi Band 4 dengan konsentrasi MPT lapangan.

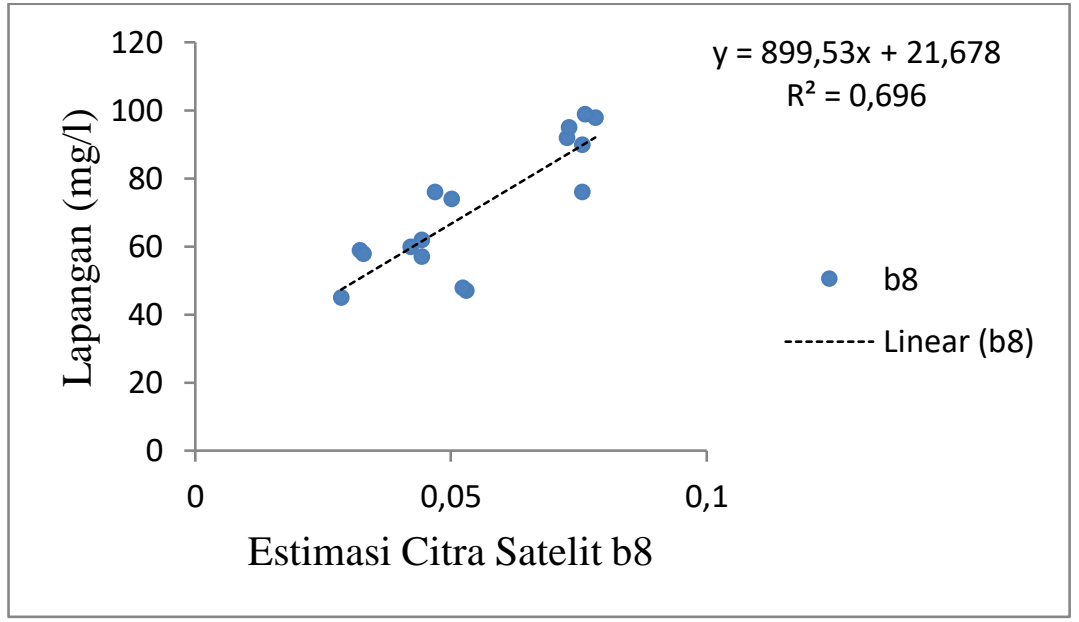

Gambar 8. Grafik Regresi Band 8 dengan konsentrasi MPT lapangan.

Berdasarkan uji korelasi grafik regresi dapat diketahui bahwa algoritma yang dibangun dengan reflektan kanal merah memiliki nilai yang lebih baik dari pada algoritma yang dibangun dengan menggunakan reflektan kanal hijau, biru dan NIR. Sehingga 
algoritma baru dibangun berdasarkan nilai yang diperoleh dari reflektan remote sensing citra kanal merah. Menunjukkan bahwa nilai koefisien determinasi $\left(\mathrm{R}^{2}\right)$ tertinggi dimiliki oleh band merah sebesar 0,9075 sehingga dipilih 16 stasiun yang digunakan untuk generate algoritma baru dan 10 stasiun untuk uji akurasi. Dari persamaan eksponensial antara nilai band merah dengan nilai konsentrasi data lapangan menghasilkan koefisien persamaan algoritma mpt baru. Algoritma Material Padatan Tersuspensi baru :

$$
\operatorname{MPT}(\mathrm{mg} / \mathrm{L})=27.256 x e^{8,6554 \times \text { Rrs red }} \text {. }
$$

Berdasarkan pengolahan data citra satelit dan data mpt lapangan sebanyak 26 stasiun terpilih, hasil yang diperoleh menunjukkan jika konsentrasi material padatan tersuspensi pada setiap stasiun yang dipilih untuk generate algoritma baru mendapatkan nilai konsentrasi tertinggi pada rentang $88,44 \mathrm{mg} / \mathrm{l}$ pada daerah muara sungai yang ditandai dengan coklat tua pada peta hingga nilai konsentrasi terendah $35,92 \mathrm{mg} / \mathrm{l}$ pada daerah laut lepas yang ditandai warna biru pada peta.

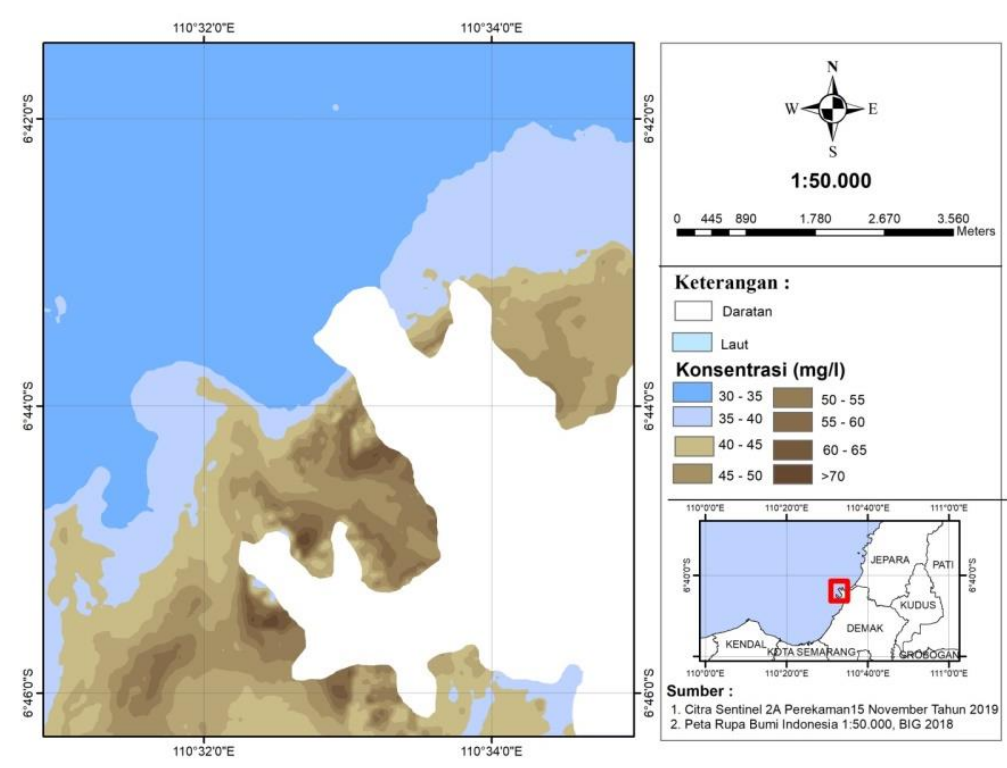

Gambar 9. Peta Sebaran MPT Algoritma Baru

Berdasarkan hasil pendugaan citra satelit menunjukkan jika konsentrasi material padatan tersuspensi di Kota Pesisir Demak, algoritma mendapatkan nilai konsentrasi tertinggi pada rentang $88,44 \mathrm{mg} / \mathrm{l}$ pada daerah muara sungai yang ditandai dengan warna coklat tua pada peta hingga nilai konsentrasi terendah 35,92 mg/l pada daerah laut lepas yang ditandai warna biru pada. Terkumpulnya MPT pada muara sungai dikarenakan muara sungai merupakan stasiun terdekat dari daratan dimana daratan merupakan sumber terbesar penyuplai MPT. Hal ini sesuai dengan pernyataan (Setiady \& Permana, 2016) yang menyebutkan jika perpindahan sedimen pantai dapat diakibatkan oleh arus sungai, gelombang, arus pasang surut, angin. Arus laut akan menyebabkan terjadinya resuspensi sedimen sehingga menyebabkan nilai konsentrasi material padatan tersuspensi akan cenderung lebih tinggi di dekat daratan. Arah dan kecepatan arus akan sangat mempengaruhi pada persebaran dan nilai konsentrasi material padatan tersuspensi. 


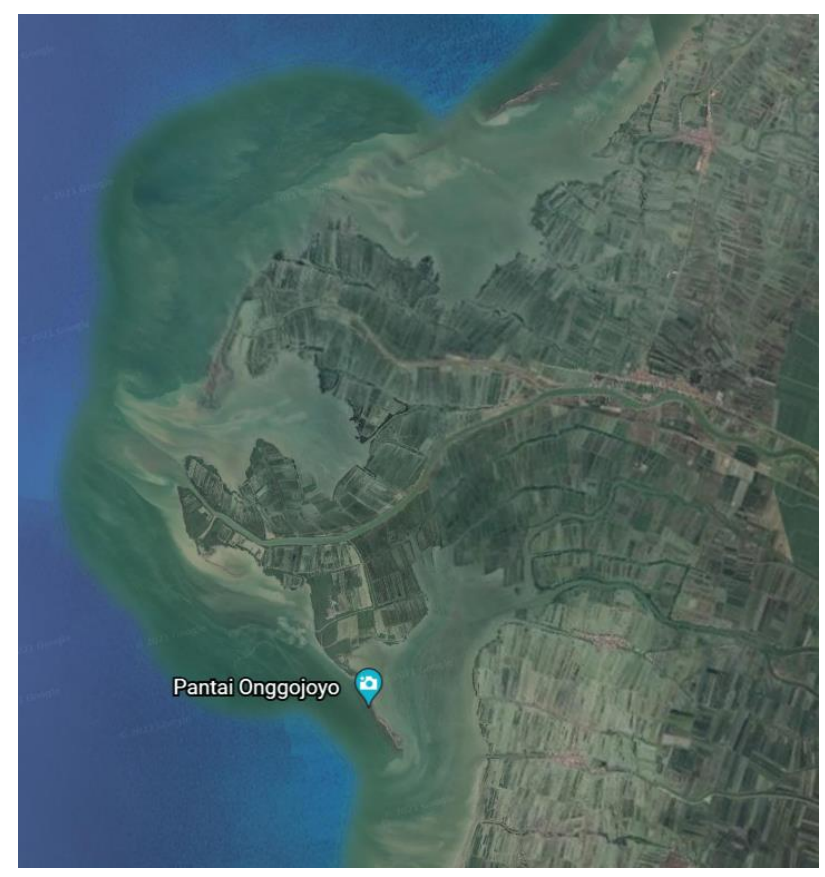

Gambar 10. Penentuan Lokasi Dermaga Baru

Berdasarkan analisis spasial penentuan lokasi strategis dermaga baru dengan mempertimbangkan studi literasi dan penelitian yang telah dilakukan Lokasi Dermaga yang tepat dapat dilihat pada gambar dengan mempertimbangkan aspek sosial dan aspek teknis dalam pembangunan.

\section{Kesimpulan}

Hasil analisis menunjukkan bahwa penggunaan kanal merah pada Citra Sentinel2A memiliki hasil yang baik untuk memetakan sebaran material padatan tersuspensi Sebaran Material Padatan tersuspensi di perairan Delta Wulan memiliki konsentrasi 35,92 $\mathrm{mg} / \mathrm{l}$ hingga 78,47 mg/l, konsentrasi yang tinggi terdapat pada bagian utara dan timur muara sungai yang berupa teluk. Hasil uji korelasi algoritma terbaik B4 dengan nilai korelasi $\left(\mathrm{R}^{2}\right)$ 0,9075 dan nilai Uji Akurasi RMSE 3,8895. Arus Pasang Surut sangat berpengaruh terhadap sebaran material padatan tersuspensi. Pada saaat kondisi pasang menuju surut arus bergerak dominan dengan daya kecepatan antara 0.0096m/dt $0.122 \mathrm{~m} / \mathrm{dt}$. Hal ini berpengaruh pada perubahan Kota pesisir yang dinamis dan dapat dijadikan untuk mitigasi bencana. Pertimbangan penentuan lokasi dermaga setelah analisis teknis dapat dilihat posisi dermaga sangat baik dan meninjau aspek sosial sangat cocok denkat dengan permukiman. 


\section{Bibliografi}

Atmodjo, Warsito. (2011). Studi penyebaran sedimen tersuspensi di muara Sungai Porong Kabupaten Pasuruan. Buletin Oseanografi Marina, 1(1).

Gatti, A., \& Bertolini, A. (2015). Sentinel-2 Products Specification Document. Rapport technique. European Space Agency. Consulté sur https://sentinel. esa. int/documents ....

Hossain, AKMA, Jia, Y., \& Chao, X. (2010). Development of remote sensing based index for estimating/mapping suspended sediment concentration in river and lake environments. Proceedings of 8th International Symposium on ECOHYDRAULICS (ISE 2010), 578-585.

Huang, Jing, Pan, Cun hong, Kuang, Cui ping, Zeng, Jian, \& Chen, Gang. (2013). Experimental hydrodynamic study of the Qiantang River tidal bore. Journal of Hydrodynamics, 25(3), 481-490.

Jiyah, Jiyah, Sudarsono, Bambang, \& Sukmono, Abdi. (2017). Studi Distribusi Total Suspended Solid (TSS) Di Perairan Pantai Kabupaten Demak Menggunakan Citra Landsat. Jurnal Geodesi Undip, 6(1), 41-47.

Manurung, Jefri Gunawan, Suryoputro, Agus Anugroho Dwi, \& Hariadi, Hariadi. (2017). Analisis Pengaruh Pasang Surut Terhadap Sebaran Muatan Padatan Tersuspensi Di Sekitar Perairan Muara Sungai Wulan, Kabupaten Demak, Jawa Tengah. Journal of Oceanography, 6(1), 68-78.

Minarrohman, Ghilman. (2017). Simulasi arus dan distribusi sedimen secara 3 dimensi di pantai selatan jawa. Institut Teknologi Sepuluh Nopember.

Poerbandono, Djunarsjah E., \& Djunarsjah, E. (2005). Survei hidrografi. Refika Aditama. Bandung.

Putri, Sebrina Suseno, Muskananfola, Max Rudolf, \& Hendrarto, Boedi. (2017). Kajian Perubahan Spasial Delta Wulan Demak Dalam Pengelolaan Keberlanjutan Wilayah Pesisir.

Qanita, Humaira, \& Subiyanto, Sawitri. (2019)._Analisis Distribusi Total Suspended Solid Dan Kandungan Klorofil-A Perairan Banjir Kanal Barat Semarang Menggunakan Citra Landsat 8 Dan Sentinel-2A. Jurnal Geodesi Undip, 8(1), 435445 .

QHOMARIYAH, LAILATUL. (2015). Analisa Hubungan Antara Pasang Surut Air Laut Dengan Sedimentasi Yang Terbentuk (Studi Kasus: Dermaga Pelabuhan Petikemas Surabaya). Institut Teknologi Sepuluh Nopember.

Setiady, Deny, \& Permana, Asep. (2016). Proses Sedimentasi Sungai Kalijaga, Dan Sungai Sukalila Perairan Cirebon. Jurnal Geologi Kelautan, 5(1). 
Analisis Penentuan Pembangunan Dermaga Berdasarkan Analisis Citra Sentinel 2a di Perairan Delta Wulan Kota Pesisir Demak

Suryono, Chrisna Adhi, \& Rochaddi, Baskoro. (2017). Kualitas perairan di daerah fishing ground nelayan kerang di pesisir timur Kota Semarang. Jurnal Kelautan Tropis, 20(1), 42-47. 